\title{
A SOCIAL AND ECONOMIC PERSPECTIVE ON THE LIBYAN CONFLICT. TRIBALISM AND OIL CASES
}

\author{
Anca DINICU \\ “Nicolae Bălcescu” Land Forces Academy, Sibiu, Romania \\ anca_dinicu@yahoo.com
}

\begin{abstract}
The Libyan conflict has become an issue at the global level since its beginning. The foreign aid and support help got by the revolutionaries in their attempt to overthrow the Qaddafi regime and the role of tribes not only during these events but also afterwards, the country's strategic position and oil reserves are the main points of interest when considering the North African internationalized civil war. While the role played by the tribes in stabilizing the political and social framework still lays at crossroads, being extremely controversial, the economic value and strategic importance of oil, for domestic actors as well as the international ones, are above any doubt.
\end{abstract}

KEYWORDS: conflict, internationalization, tribe, oil, security vacuum

\section{Introduction}

Born as a great hope and even compared to the revolutions of 1989 in Central and Eastern Europe (as a natural shift to the neighboring geographical area, albeit at a distance of more than two decades and in a completely different cultural region), but also with the European revolutions of 1848 (since neither those European nor the Arab peoples had experienced democracy), the Arab Spring, 10 years later, hasn't yet brought the desired political and economic changes, although it generated a series riots at the level of Arab societies (some transformed into permanent civil wars) and induced some political transformations. The autocracy, however, proved a great capacity for resilience, and where the restoration was not accomplished, the cause was the civil war which gathered under its shadow several states, including Libya. But this concerning reality does not exclude the possibility that the revolts that defined the Arab Spring will constitute, in the following decades, "the catalyst that opened the door to a regionwide process of democratization" (Makdisi, 2017). Because today one thing is certain: the old Arab political and economic world has vanished, without establishing a new order specific to this region of overwhelming diversity. In fact, "the new order is fundamentally one of disorder" (Lynch, 2018).

This paper once again puts the Libyan conflict under the spectrum of analysis, by taking into account the element that led to the internationalization of the conflict, namely the oil issue, and by highlighting not only the particularity of Libyan society but especially the role played by tribes as a form of socio-political organization.

\section{Methodology}

The research paper is the result of direct observation of a well-known conflict, along with geopolitical tailored events that 
were generated by it, and of a literature review relevant for dealing with the international security subject from the conflict and socio-political organization perspectives, and especially the ones concerning the Libyan specificity.

\section{General Analysis Framework Specific to the Libyan Conflict 3.1. Conceptual Clarifications}

Understanding the Libyan conflict, a politically inefficient and economically disastrous consequence of the Arab Spring, requires at least two conceptual clarifications - defining the notion of the tribe and clarifying how an internal conflict becomes internationalized.

- A tribe is a form of social organization, historically anchored between band-level and state-level, and which is not only specific to some geographical regions but is an experience lived by the whole of humanity. A "patronage organization", just like a band is understood as being an earliest expression of human social association, "the tribe is based on a principle of descendants from a common ancestor, which allows the scale of society to vastly increase" (Fukuyama, 2015). A form of social organization, the tribe has its own "authority structure" and is individualized at the societal level through a "shared or common identity" (Viotti \& Kauppi, 2002).

It should be noted that this term is used today in a variety of meanings, which indicates that its sense should not be generalized, but adapted to the context it describes. Moreover, the use of the term in a political context has given rise to several grievances in some African societies, being used by governments from Rhodesia (since 1980, Zimbabwe) and South Africa (during the Apartheid system) to journalist "as a code of disorganized, primitive and less civilized people” (Wiley, 1981).

While the term "tribe" designates a group or a clan, the term "tribalism", like any other "ism" specific to political and ideological language (capitalism, nationalism, communism), is referring to a set of attitudes and opinions held, in this case, by a tribe, about itself, and also about the relationships developed with other tribes.

- Regarding the internationalized internal conflict, today almost all civil wars are marked by external intervention, the isolation of such an event being extremely complicated in the context of globalization. Internationalization is explained by power politics that is played worldwide and by the existence of very attractive areas from a strategic and/or economic point of view, but politically unstable or even collapsed as the capacity of what was once the legitimate political establishment to manage the organization and functioning of the society on the entire national territory. At the same time, the internationalization of the conflict occurs as a consequence of its fluid nature displayed beyond national borders, either as a result of the wave of refugees or the attitude of neighboring states that envisage their national interests and/or regional "status quo" threatened. Internationalization, therefore, involves a direct intervention by foreign actors (states, international organizations, and NGOs), at the global and regional level, but also indirectly, in the sense of obtaining advantages by playing in a seemingly secondary plan and supporting one of the parties. Which means maintaining the conflict. Contemporary reality provides examples of such conflicts, and we are talking about situations such as those in Syria, Iraq, Yemen, or, last but not least, Libya.

Regarding this issue, the Libyan conflict can be analyzed from the perspective of a domestic dimension and the perspective of an international dimension. The first should refer to the internal forces involved in the dispute, namely the two parallel governments (of which only the one in Tripoli benefited from UN recognition, and then from the EU) which divided their country in terms of 
territory, but also control over resources (oil and financial), as well as the dense social fabric of the approximately 100 tribes, obviously not all having the military and economic power to balance the balance the power game between country's Eastern and Western parts.

Concerning the international dimension, the analysis should take into account competition for power (Saudi Arabia, Egypt, Iran, Israel, Turkey) in the MENA region, as well as the fight for supremacy between the Arab states, access to and control of reserves and transport routes of oil and natural gas, the arms trade seen as a supplier for the primary parties of the conflict, and even the potential benefits that could come from the country's reconstruction contracts, not to mention the economic contracts concluded by the Qaddafi regime and which have not found financial fulfillment in external partners. The internationalization of the civil war was therefore almost mandatory.

The perpetuation of the conflict between the two main actors (the Government of the National Accord, the only internationally recognized governing body, and the Libyan National Army) who divided their country and the distinctive structure of the Libyan society, including issues that contained a religious side and which existed since the time of Qaddafi (Salafi-jihadism), but also the emergence of terrorist groups in a civil war fought very close to Europe would raise the stakes of everything that followed as a result of the Revolution of 2011. Not only that this conflict had the inevitable imprint of internationalization (after all, as I have shown, absolutely explicable only in the context of globalization itself), but even Qaddafi's ousting from governing was done with the support of foreign intervention, namely NATO acted under the principle of Responsibility to Protect (R2P). As it is stated in the Resolution adopted by the General Assembly on 16 September 2005,
"Each individual state has the responsibility to protect its populations from genocide, war crimes, ethnic cleansing and crimes against humanity... We accept that responsibility and will act in accordance with it... The international community, through the United Nations, also has the responsibility to help protect populations from genocide, war crimes, ethnic cleansing, and crimes against humanity. In this context we are prepared to take collective action, in a timely and decisive manner, through the Security Council... should peaceful means be inadequate and national authorities are manifestly failing to protect their populations from genocide, war crimes, ethnic cleansing, and crimes against humanity" (United Nations General Assembly, 2005).

\subsection{Elements of Strategic Interest Specific to the Libya File}

Within a complex process of global geopolitical redefinition of the world, Libya stands as a point of attraction on the map of foreign policies projected by the great powers, but also by the regional powers. The elements that determine the inclusion of this country in the power game in the MENA region are:

- Strategic position in the Mediterranean. The territorial vastness $\left(1,759,540 \mathrm{~km}^{2}\right.$, the 17 th largest in the world and the fourth largest African country after Algeria, Sudan, and the Congo) makes Libya occupy a special strategic position: situated in the middle of North Africa, between the two parts of the Arab world (Maghreb and Mashreb) and in the vicinity of Europe (the distance between Tripoli and Lampedusa is $290 \mathrm{~km}$ ), has a length of the shore to the Mediterranean Sea of 1,900 km, and is a gateway to sub-Saharan Africa.

- Considerable oil and natural gas reserves. Libya's oil reserves are the largest in Africa and the seventh-largest globally, with 48.36 billion barrels as of the end of 
2018, while the natural gas reserves encounter 1.50 billion cu. m. (Organization of the Petroleum Exporting Countries) ranking it the $21 \mathrm{st}$ globally and representing $0.8 \%$ from de world share.

The strategic position and the oil issue are the stable elements of the geopolitical picture, and are complemented by a contextual one, manifested in the form of internal conflict which, as we have already shown, benefits from special attention from several states. It is thus possible from this point of view a twopronged analysis which intersects one with each other the points aimed at the struggle for power and economic interests (access and control over hydrocarbon reserves) pursued by conflict's own stakeholders but also seeking gains from potential future contracts to rebuild the country once the conflict is over.

\section{Social Dimension of the Conflict. The Tribes' Issue}

A main feature of Libyan society is tribalism, the country being shaped, "for better or for worse, around a tribal and regional system" (Lamma, 2017).

The tribal regime is a historical heritage from the Ottoman and Italian occupations and, as anachronistic as it may seem, this form of organization managed to survive the revolution, proving a special capacity for resilience but at the same time condemning the country to social immobility, despite demands expressed by the young generation eager for change. The tribes not only did survive, but they filled the institutional vacuum created by the dissolution of the state and the beginning of the power struggle between the rival domestic actors (Libya: what is behind the rise of the tribes).

The support given to the last ones by the various tribes, who even engaged in a direct struggle one with each other, actually reflected older animosities among them. The fall of the political regime under the revolt of the citizens led not only to a political vacuum but also generated a security one, the two complementing each other. Obviously, in practical terms, the security vacuum manifested itself in the form of fights between militias that supported the interests of different tribal groups.

The disregard for the social and quasi-political importance of tribes by foreign actors involved in various forms in the conflict can be considered a cause of excessive prolongation of a conflict born from a revolution movement that solved relatively quickly and radically the problem of the authoritarian nature of the Qaddafi regime.

Tribalism is not a characteristic specific only to the Libyan society, many other social constructions of the Arab societies being rooted in it. What is to be noticed is the importance maintained by it even nowadays in regarding with the society leadership and to a lesser extent with the state leadership.

The involvement of the tribes in the conflict and their true role in guiding events and balancing the confrontation between the two main internal actors (the Government of the National Accord, and the Libyan National Army) are viewed circumstantially and explained through a two-way approach. The tribes are: "part of the problem or a solution?" (Libyan tribes: Part of the problem or a solution?), “factor for fragmentation or cohesion?". (Lamma, 2017), "central actors in either activating the revolution or suppressing it" (Hweio, 2012, pp. 11-121).

\section{Economic Dimension of the Conflict. The Oil Issue}

In Libya, the story of oil has begun in 1955, when the Petroleum Law authorized the drilling of oil wells. Nowadays, the industry is being run by the state-owned National Oil Corporation (NOC), along with several smaller subsidiaries and some foreign firms. In fact, some of the NOC 
subsidiary companies are joint ventures with foreign investors. The most important foreign players are the Italians from ENI, the French from Total, the Spaniards from Repsol, and the Austrians from OMV (Who owns Libya's oil?).

Although a small producer compared to other OPEC member states, Libyan oil is in high demand in the global market due to its outstanding quality, which makes it suitable for use as a transportation fuel and as an alternative source to power generation (Morse \& Lee, 2011). The conflict has put great pressure on oil production which is the primary source of revenue. Increasing oil production to at least 1 million barrels per day by the end of November 2020, from a current 500,000 barrels per day (Turak, 2020) and less than 100,000 in early September (Turak, 2020), as a result of the ceasefire agreement concluded in November 2020 in Geneva, it could prove to be a double-edged sword. It could either be the basis for economic growth or generate new instability as a result of competition for access to this resource. But even in the happiest case, Libya has to deal with serious economic problems as a result of the infrastructure destroyed by the war or the power of the black market (Miller \& Truitte, 2017).

The great revenue is not the only benefit oil brings for the Libyan economy. It is the industry that offers job opportunities, given that 94 percent of government revenues come from oil production (Libya GDP Annual Growth Rate) and is the breeding ground for foreign investment that is directly related to political stability.

\section{Conclusions}

It is obvious that the chaos of the political governance in Libya and the military fragmentation that is taking place for almost a decade have favored the lawlessness and endangered to a great extend the economic situation. And for solving the problems not a military answer is needed, but a political decision in order to solve security and economic problems. In this respect, the "permanent ceasefire" settled in Geneva, on the $23^{\text {rd }}$ of October this year, may be auspicious. But nothing is certain. Only oil is the only stable thing in Libyan politics and economy. And if the money obtained from oil exports will be properly managed politically and economically, leading to the development of society (including culturally), then the tribes, until today an important wheel in the functioning of society, will lose their importance. It is unlikely, however, that these things will happen in the near future.

Building security implies strong centralized governance, able to generate fair competition among the domestic actors, and to attract and benefit from foreign investors. Both directions of action are strongly conditioned by the money obtained from the exploitation and sale of oil. The entire political struggle, regardless of whether it is supported by the military, is based on who is in charge with the Libyan oil. The existence of tribes only complicates the situation.

\section{REFERENCES}

Fukuyama, F. (2015). Political Order and Political Decay. From the Industrial Revolution to the Globalisation of Democracy, London: Profile Books LTD, p. 89.

Hweio, H. (2012). Tribes in Libya: From Social Organization to Political Power. African Conflict \& Peacebuilding Review, Vol. 2, Issue 1, 111-121. 
Lamma, M. B. (2017). The Tribal Structure in Libya: Factor for fragmentation or cohesion? available at: https://www.frstrategie.org/web/documents/programmes/observatoiredu-monde-arabo-musulman-et-du-sahel/publications/en/14.pdf, accessed on 16 September 2020.

Libya GDP Annual Growth Rate, available at: https://tradingeconomics.com/libya/gdpgrowth-annual, accessed on 14 October 2020.

Libya: what is behind the rise of the tribes! available at: https://www.theafrica report.com/38093/libya-what-is-behind-the-rise-of-the-tribes/, accessed on 16 September 2020.

Libyan tribes: Part of the problem or a solution? available at: https://www. middleeastmonitor.com/20180808-libyan-tribes-part-of-the-problem-or-a-solution/. accessed on 17 September 2020.

Lynch, M. (2018). The New Arab Order. Power and Violence in Today's Middle East, available at: https://www.foreignaffairs.com/articles/middle-east/2018-08-14/new-arab-order, accessed on 16 September 2020.

Makdisi, S. (2017). Reflections on the Arab Uprisings. International Development Policy, Vol. 7, Combining Economic and Political Development. The Experience of MENA, available at: https://journals.openedition.org/poldev/2280, accessed on 16 September 2020.

Miller, E., \& Truitte, K. (2017). Filling the Vacuum in Libya. The Need for a Political, Not Military Solution, available at: https://www.foreignaffairs.com/articles/libya/2017-0718/filling-vacuum-libya, accessed on 17 September 2020.

Morse, E. L., \& Lee, E. G. (2011). The Libyan Oil Tap. How to Get the Country's Production Back Online, available at: https://www.foreignaffairs.com/articles/libya/2011-0906/libyan-oil-tap, accessed on 10September 2020.

Organization of the Petroleum Exporting Countries, available at: https://www.opec.org/, accessed on 01 January 2020.

Turak, N. (2020). Libya's ramped-up oil output throws another wrench at prices and OPEC's plans, available at: https://www.bloomberg.com/news/articles/2020-11-11/libya-oiloutput-at-1-1-million-barrels-a-day-toughens-opec-task, accessed on 27 October 2020.

United Nations General Assembly. (2005). World Summit Outcome: resolution/adopted by the General Assembly, 24 October 2005, A/RES/60/1), available at: https://www.un.org/ en/development/desa/population/migration/generalassembly/docs/globalcompact/A RES 60 1.pdf, accessed on 10 October 2020.

Viotti, P. R., \& Kauppi, M. V. (2002). International Relations and World Politics: Security, Economy, Identity, Prentice Hall.

Who owns Libya's oil? available at: https://uwidata.com/11804-who-owns-libyas-oil/, accessed on 10 September 2020.

Wiley, D. (1981). Using “Tribe" and "Tribalism" Categories to Misunderstand African Societies, available at: https://www.africa.upenn.edu/K-12/Tribe.html, accessed on 16 September 2020. 